\title{
Hydraulic numerical analysis of groundwater in the left hinterland of the Mostar hydroelectric power plant dam
}

\author{
Petra Merdžo \\ University of Mostar, Faculty of Civil Engineering, M.Eng.C.E. \\ petra.merdzo@gmail.com \\ Mirna Raič \\ University of Mostar, Faculty of Civil Engineering, Ph.D C.E. \\ mirna.raic@gf.sum.ba
}

\begin{abstract}
This paper presents a research conducted as part of development of the graduation thesis entitled: "Hydraulic numerical analysis of groundwater in the left hinterland of the Mostar hydroelectric power plant dam", which was developed and successfully defended at the Faculty of Civil Engineering, University of Mostar in 2020. The Mostar hydroelectric power plant, in tandem with the Salakovac HPP, levels the flows in the downstream course of the Neretva River. In the area around the embankment and the diaphragm wall, there are indications of filtration deformations of soil, and development of dominant directions of groundwater flows. The paper examines the area of the left hinterland of the Mostar hydroelectric power plant dam in the MAGNET 4 WATER program, and compares the obtained results with the existing verified results from the DHI WASY FEFLOW program as well as the field results. It was concluded that the spatial model is suitable for further research and analyses, e.g. for monitoring groundwater flows in the area, and for the analysis of risks of contaminant transport underground the left hinterland of HPP Mostar.
\end{abstract}

Key words: Mostar hydroelectric power plant, groundwater flow, MAGNET, FEFLOW, model

\section{Hidraulička numerička analiza podzemnih voda na području lijevog zaobalja brane hidroelektrane Mostar}

Sažetak: Ovaj rad daje prikaz istraživanja urađenog u sklopu izrade diplomskog rada pod naslovom: „Hidraulička numerička analiza podzemnih voda na području lijevog zaobalja brane hidroelektrane Mostar", koji je urađen i uspješno obranjen na Građevinskom fakultetu Sveučilišta u Mostaru 2020. godine. Hidroelektrana Mostar, u pogonskoj sprezi s HE Salakovac, vrši izravnanje protoka u nizvodnom toku rijeke Neretve. Na prostoru oko nasipa i dijafragme ima naznaka filtracijskih deformacija tla, te razvoja dominantnih pravaca strujanja podzemnih voda. $U$ radu je ispitano područje lijevog zaobalja brane hidroelektrane Mostar $u$ programu MAGNET 4 WATER, te izvršena je usporedba dobivenih rezultata $s$ već postojećim verificiranim rezultatima iz programa DHI WASY FEFLOW kao i rezultatima $S$ terena. Zaključeno je da je prostorni model pogodan za daljnja istraživanja i analize npr. kod monitoringa strujanja podzemnih voda na području, te kod analize rizika od pronosa zagađenja u podzemlju lijevog zaobalja HE Mostar.

Ključne riječi: hidroelektrana Mostar, tečenje podzemnih voda, MAGNET, FEFLOW, model

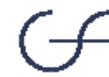


Merdžo, P., Raič, M.

Hydraulic numerical analysis of groundwater in the left hinterland of the Mostar hydroelectric power plant dam

\section{INTRODUCTION}

Intensive construction activity on the surface and underground has imposed the need to solve complex problems caused by the existence of groundwater. Hydrogeological investigations are carried out for construction of hydraulic structures as well as for water supply of settlements and industrial facilities, irrigation, protection against groundwater pollution, etc. Like other research works, hydrogeological investigations begin by studying existing data on results of previous studies, after which the necessary further investigations are defined.

Model tests are used when comprehensively studying hydrogeological systems. Hydrogeological systems are generally very complex, and for analysis it is necessary to simplify them, i.e. to create a system model that includes all the essential properties of the system.

This paper examines the possibility of using the MAGNET 4 WATER program created at Michigan State University in the United States for karst areas. The MAGNET 4 WATER program includes modeling methods as well as its own database from which it retrieves the data available to it for the study area. The program is relatively newer, and does not include much data from Europe, especially the Balkans, because most of the modeling made in this program is related to Michigan.

The objective of this paper is to verify the application of the spatial stationary model of groundwater flow in the considered area of the left hinterland of the hydroelectric power plant Mostar in order to determine the dominant directions of groundwater flows, and compare the results with existing verified results from the DHI WASY FEFLOW program. The modeling was carried out based on the existing database. In addition to this study, a transport analysis was conducted and these results were compared with the existing field results as well as the results from the DHI WASY FEFLOW program.

The model could be used to simulate the underground conditions in case of insufficient groundwater level monitoring data, as well as to predict the distribution of groundwater levels depending on the operation of the hydroelectric power plant, as well as atmospheric effects, and to examine contaminant transport to the underground in the event that pollution sources occur.

The paper consists of 5 chapters. The first is an introductory one, discussing the objective and purpose of the paper, and includes a description of the content of chapters. The second chapter describes the study area, and existing field studies. The third chapter explains the MAGNET 4 WATER software and how to use it. The fourth chapter presents the conceptual model of the study area, and the two subchapters present the test results (groundwater level, volume of water seeping from the domain, groundwater flow velocities, transport of tracers to the underground) as well as their verification. The fifth chapter is final and it presents the conclusions of this study.

\section{STUDY AREA}

The Mostar hydroelectric power plant is located $6 \mathrm{~km}$ north of Mostar. It was first commissioned in 1987, and after it was completely devastated in the 1992 war, it was recommissioned in 1997. It was constructed in the period 1983-1987. In the planned Middle Neretva Project from 1953, HPP Mostar, along with HPP Grabovica and HPP Salakovac, is part of a complex project of three dam power plants, each playing a different energy role. HPP Mostar has an important role in this project for regulating more uniform operation and 
Merdžo, P., Raič, M.

Hydraulic numerical analysis of groundwater in the left hinterland of the Mostar hydroelectric power plant dam

leveling the operation of upstream hydroelectric power plants. It is a reservoir dam plant, built as the most downstream one in a series of plants on the middle Neretva, which use the water of Neretva River for hydropower purposes.

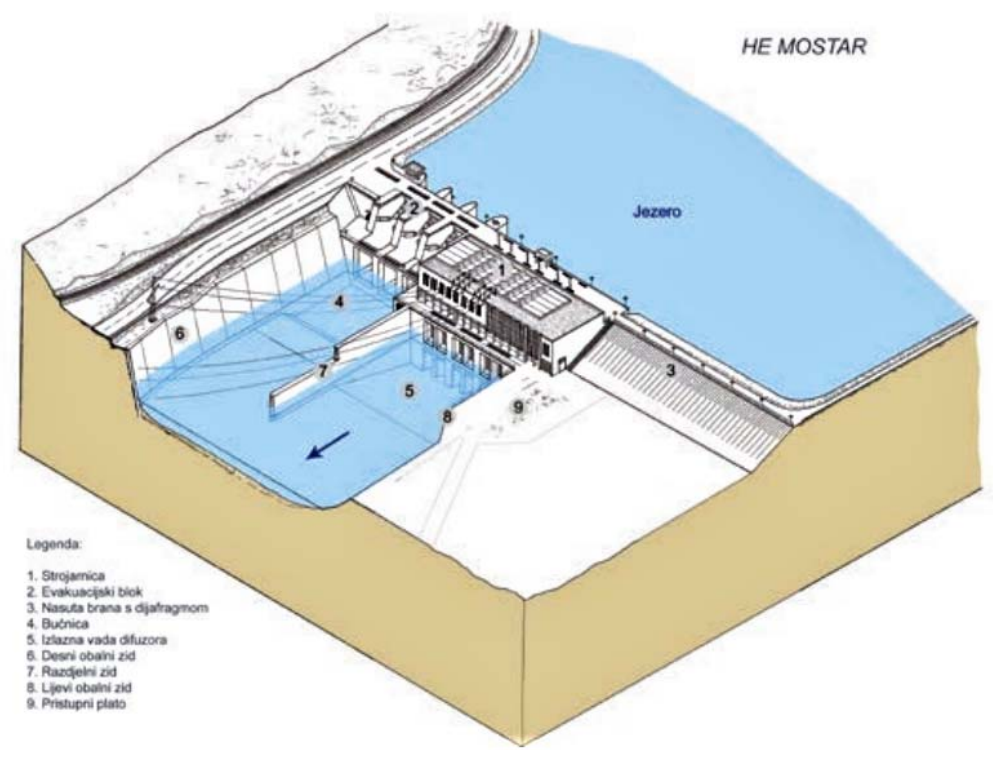

Figure 1. Schematic view of HPP Mostar [1]

HPP Mostar consists of the following structures:

- Water storage reservoir located in the Neretva riverbed in the western part of Bijelo Polje. The length of the reservoir is about $11.0 \mathrm{~km}$, and the available storage capacity at a normal top water level of $78.0 \mathrm{~m}$ a.s.l. is $6.37 \times 10^{6} \mathrm{~m}^{3}$.

- This is a combined-type dam with two structural and functional units: the concrete gravity dam with turbine hall in the Neretva riverbed and outlet works on the right side, and the rockfill part of the dam on the left side that circularly transforms into a flood embankment.

- The rockfill part of the dam with impermeable diaphragm is trapezoidal in shape, $106 \mathrm{~m}$ long, in the left side it circularly transforms into a flood embankment 2500 $\mathrm{m}$ in length. A $134 \mathrm{~m}$ long clay-concrete diaphragm was constructed as an impermeable core in the rockfill part of the dam. The impermeable grout curtain of the dam was constructed in a total length of $310 \mathrm{~m}$, with different depths in sides, under the dam and in a smaller part of the left side.

- Outlet works for high water are three spillway fields located on the right side of the structure, with a maximum capacity of $3,070 \mathrm{~m}^{3} / \mathrm{s}$ and the bottom outlet with a capacity of $180 \mathrm{~m}^{3} / \mathrm{s}$. A biological minimum of $50 \mathrm{~m}^{3} / \mathrm{s}$ is discharged in case of generator idling because the power plant is the last one in the Neretva River basin.

All distribution plants of the hydroelectric power plant as well as three generators with Kaplan turbines in reinforced concrete spirals are located in the turbine hall. The installed flow of a generator is $120 \mathrm{~m}^{3} / \mathrm{s}$ for the maximum power of one unit, and $360 \mathrm{~m}^{3} / \mathrm{s}$ for the maximum power of all three units. The total installed capacity is $72 \mathrm{MW}$. The average energy capability is $310 \mathrm{GWh}$ [1]. 
Merdžo, P., Raič, M.

Hydraulic numerical analysis of groundwater in the left hinterland of the Mostar hydroelectric power plant dam

Construction of HPP Mostar and raising the water level in the Neretva riverbed to the designed top water level of $78.00 \mathrm{~m}$ a.s.l. have changed the conditions influencing the formation of groundwater regimes. The effects of the changed conditions on the area have been the subject of long-term considerations with collection of the necessary data on geological and hydrogeological (filtration) characteristics of the environment in which the facility with the storage reservoir is located. Filtration problems, forecast of losses as well as position of groundwater level in relation to ground surface were solved on the basis of available data from previous studies. Special attention is paid to determining the real filtration properties of the left bank medium where the problems of seepage from the reservoir to the hinterland are more pronounced. Since the tail water level is at an elevation of $55.00 \mathrm{~m}$ a.s.l., in the dam profile area there is a large groundwater level gradient, so the groundwater flows could compromise the stability of the natural slope of the bank and of the dam itself, while water losses from the reservoir would be substantial. Therefore, during construction of the hydroelectric power plant structure, it was necessary to make a protective curtain in extension of the dam, transverse to the reservoir, so as to extend the path of groundwater flow.

Solving the problem involved collecting the necessary documentation on the basis of which the results of this work could be reliably compared with the results of previous studies. It was necessary to collect all input data about previous investigations. It was also necessary to assign appropriate filtration coefficients to each layer in order to obtain a realistic representation of the studied area, and to set boundary conditions based on known field data.

\subsection{Field investigations}

Considering the problems that needed to be solved, exploratory boring was predominantly used as the investigation method. A total of 210 exploratory boreholes or $12,000 \mathrm{~m}$ of drilling were performed in the wider area of hinterland and in the dam area. Half of the total drilling meters were used in the dam site zone [2].

The more immediate area of HPP Mostar has a specific and complex geological structure of the terrain. Investigation results on the left bank of Neretva, in the area of the rockfill dam, show that the terrain is built of Quaternary deposits (terrace material) on the terrain surface and in the river and of Neogene deposits with a bed of coal and Upper Cretaceous limestone as the lowest and oldest member - bedrock.

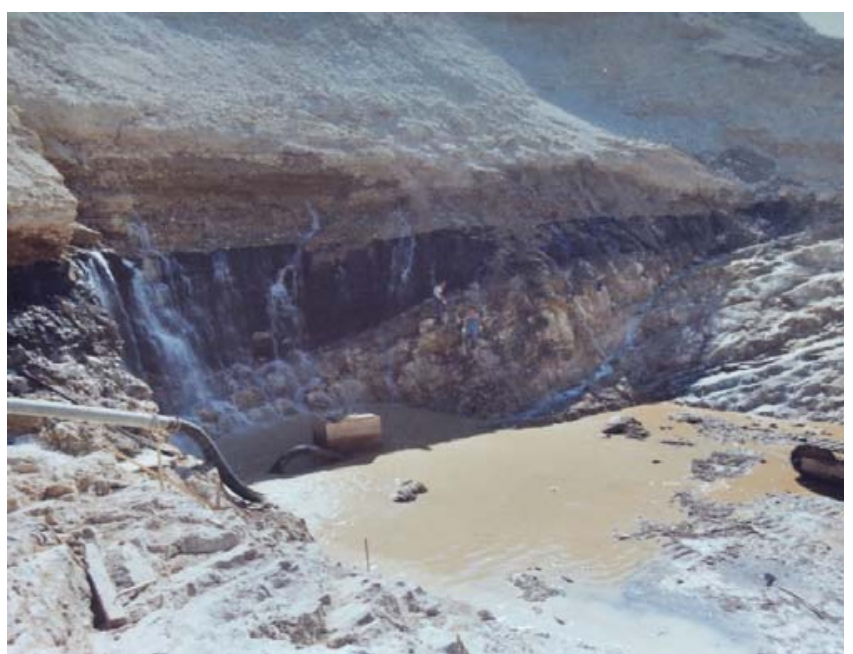

Figure 2. Layering under the rockfill part of HPP Mostar dam [3] 
Merdžo, P., Raič, M.

Hydraulic numerical analysis of groundwater in the left hinterland of the Mostar hydroelectric power plant dam

Quaternary deposits cover the entire area around the rockfill dam. Next to the Neretva bank, the rockfill dam rests directly on coal, and further towards the hinterland it is on Neogene marl, while coal occurs as a bed inside the marl. The Neogene consists of a thick deposit of marl with an up to $10 \mathrm{~m}$ thick layer of coal. A thinner layer (about $1 \mathrm{~m}$ ) of contact clay is established on marl, lying horizontally with marl and extending in the direction of the left hinterland. Through exploratory work and during the construction of the grout curtain and diaphragm, it was proved that there are four hydrogeological media in the dam area, with different hydrogeological characteristics [4].

As part of the investigations of the consequences of seepage flows, underground flows were marked with Na-fluorescein in 5 piezometers with 6 tests in the left hinterland of the HPP Mostar reservoir. The dyeing shows that seepage of water from the reservoir takes place in a relatively limited zone around the diaphragm end with discharge along the left bank to the bridge. The exploration results provided sufficient data for preliminary conclusions on the main water filtration paths and on the character of the flows.

Based on the measured values of GWL fluctuations during a period of 3 years, the maximum and minimum groundwater levels that occurred during that time at all piezometers were determined. Using these values, a map of GWL contours was made for two different hydrological conditions - dry and wet period.

\section{MAGNET}

MAGNET (Multiscale, Adaptive Global NETwork for water) is a modeling system built on preprocessed, fully-assembled framework data, i.e., data needed to conceptualize and characterize the system (e.g., DEM (Digital Elevation Model - 3D view of ground surface), charge estimates, etc.) in a ready-to-use form at the "global scale" [5]. Even though the data provided by the system may not completely satisfy the requirements of a particular study, it provides the vast majority of data needed to build a preliminary model. Thus, the modeler can use the "data-ready" system to refine or modify the preliminary model as desired by adding study-area-specific details. The system allows users not only to access and utilize pre-processed big datasets, but also to do so in real-time and interactively.

The process begins with a global Google map that allows users to select an area of interest, and then the study area is more precisely defined with polylines. The area definition is followed by the input of data of geological characteristics of layers in the area, positions of layers, as well as filtration coefficients typical of each layer.

The user can select and enter numerous model grid options in the program. This includes the number of model nodes in the horizontal direction (west-east, NX), the number of sublayers in the vertical direction, matrix solver settings, and multiplicative factors for spatially-explicit raster files of hydraulic conductivity and recharge.

The number of nodes in the north-south direction is automatically calculated based on the NX and the shape of the model domain. In the basic version of MAGNET, the maximum number of grid cells in the $X$ direction is $N x$ max $=150$. The total number of grid cells in the $X$ and $Y$ directions is $N x^{*} N y \_\max =100 * 100=10000$ (NY is automatically calculated based on the shape/geometry of the domain). The total number of vertical numerical layers is subLyr_max $=15$, and the total number of the grid pattern cells is $\mathrm{Nx}{ }^{*} \mathrm{Ny}{ }^{*} \mathrm{Nz}$ max $=100$ * $100 * 10=100000$.

MAGNET solves 3D aquifer equations (Laplace differential equation) using the finite difference method. It offers the option of choosing the method of solving matrices, and in the default settings, the Hybrid Successive Over Relaxation method is set for solving a matrix. 
Merdžo, P., Raič, M.

Hydraulic numerical analysis of groundwater in the left hinterland of the Mostar hydroelectric power plant dam

\section{CONCEPTUAL MODEL}

To solve this problem, a three-dimensional model of the left hinterland of HPP Mostar (HEMO) was created. The area domain is drawn in MAGNET 4 WATER. On the west side it is bounded by the Neretva River, while the eastern boundary extends parallel to the route of the main road M17. The model boundary extends to a length of about $260 \mathrm{~m}$ to the north, and to a length of about $600 \mathrm{~m}$ to the south. The width of the domain is about $400 \mathrm{~m}$. The third dimension of the model was determined by defining 4 layers of materials at 23 boreholes (nodes) distributed throughout the area.

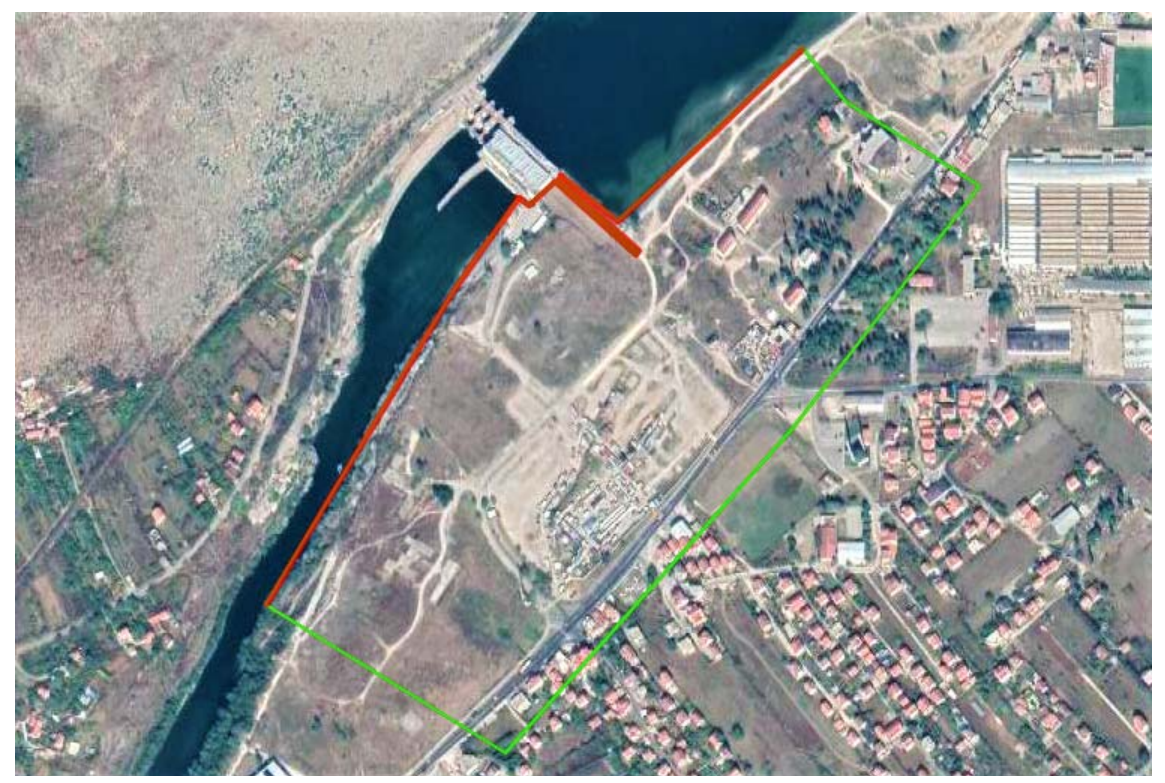

Figure 3. View of modeled area with the area of boundary conditions (red line)

In order to obtain the necessary information on the volume of water flowing around the curtain, calculation of groundwater levels in this area was performed by creating a threedimensional stationary mathematical model (49280 elementary squares per layer). By solving the Laplace differential equation for each elementary prism, the values of groundwater levels for each node located at the center of the elementary prism were obtained. The values of the filtration coefficients were qualitatively assigned to particular layers based on the analysis of geological exploration works in the area over many years. The interaction between the disregarded and modeled areas is substituted by the initial and boundary conditions. Boundary conditions are set as the absolute value of the level of head water of HPP Mostar (upstream of HPP), absolute value of the level of tail water of HPP Mostar (downstream of HPP). The north, east and south contours of the model are freely defined in the model, which means that flows are possible both into and out from the contour. 
Merdžo, P., Raič, M.

Hydraulic numerical analysis of groundwater in the left hinterland of the Mostar hydroelectric power plant dam

Table 1. Filtration coefficients for the respective layers [2]

\begin{tabular}{|c|c|c|c|}
\hline LAYER MARK & $\begin{array}{l}\text { LITHOLOGICAL } \\
\text { COMPOSITION }\end{array}$ & $\begin{array}{l}\text { HYDROGEOLOGICAL } \\
\text { FUNCTION }\end{array}$ & $\begin{array}{c}\text { FILTRATION } \\
\text { COEFFICIENT } \\
{[\mathrm{m} / \mathrm{s}]} \\
\end{array}$ \\
\hline 1 & $\begin{array}{c}\text { Diluvial terrace } \\
\text { material and } \\
\text { gravel and sand } \\
\text { with weak clayey- } \\
\text { carbonate binder }\end{array}$ & $\begin{array}{l}\text { Highly permeable } \\
\text { media }\end{array}$ & $\begin{array}{c}\mathrm{Kxx}=\mathrm{Kyy}=3 \cdot 10^{-3} \\
\mathrm{Kzz}=3 \cdot 10^{-4}\end{array}$ \\
\hline 2 & $\begin{array}{l}\text { Highly clayey } \\
\text { limestone debris - } \\
\text { well-compacted } \\
\text { conglomerate }\end{array}$ & $\begin{array}{c}\text { Partially impermeable } \\
\text { rocks with } \\
\text { hydrogeological } \\
\text { function of absolute } \\
\text { barrier }\end{array}$ & $\begin{array}{c}K x x=K y y=10^{-5} \\
K z z=10^{-6}\end{array}$ \\
\hline 3 & $\begin{array}{l}\text { Quaternary - } \\
\text { gravel, crushed } \\
\text { conglomerate, } \\
\text { sand }\end{array}$ & Permeable media & $\begin{array}{c}K x x=K y y=10^{-4} \\
K z z=10^{-5}\end{array}$ \\
\hline 4 & $\begin{array}{c}\text { Neogene marl } \\
\text { and marl with coal }\end{array}$ & $\begin{array}{c}\text { Impermeable rocks } \\
\text { with hydrogeological } \\
\text { function of absolute } \\
\text { barrier }\end{array}$ & $\begin{array}{c}\mathrm{Kxx}=\mathrm{Kyy}=10^{-6} \\
\mathrm{Kzz}=10^{-7}\end{array}$ \\
\hline
\end{tabular}

Control points at which the piezometric state is known for the set boundary conditions were marked within the model area, and these points were used for model validation. In addition to exploring the GWL, groundwater flow velocities and volumes of seepage water, an analysis of underground transport was carried out.

\subsection{Results}

After the simulation was made for stationary flow in unconfined free aquifer, the results of GWL by layers, shown in the following figures, were obtained.
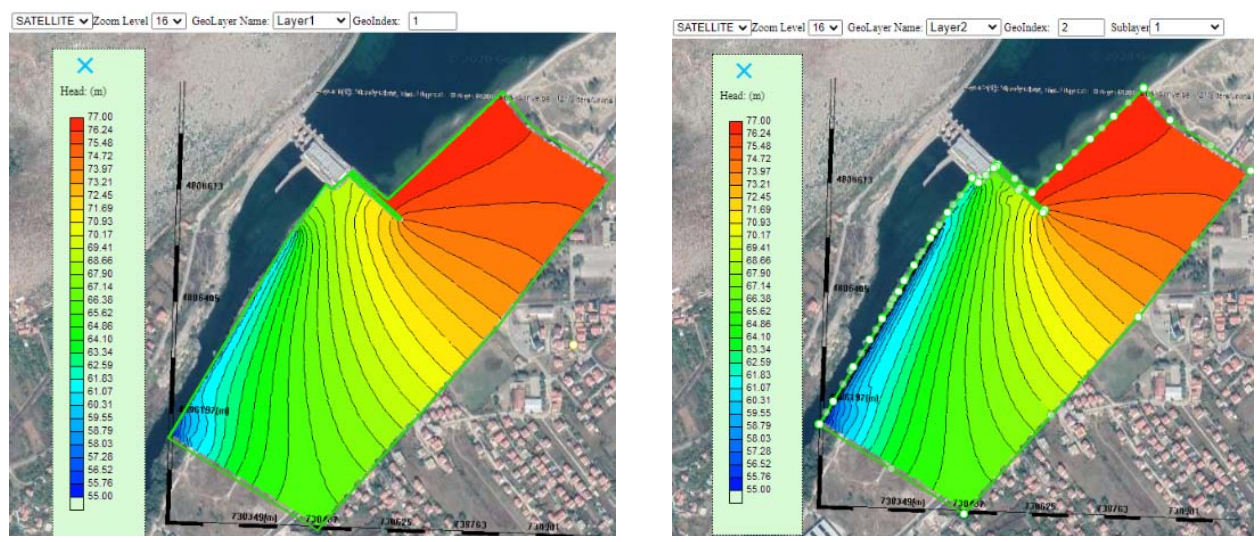
Merdžo, P., Raič, M.

Hydraulic numerical analysis of groundwater in the left hinterland of the Mostar hydroelectric power plant dam
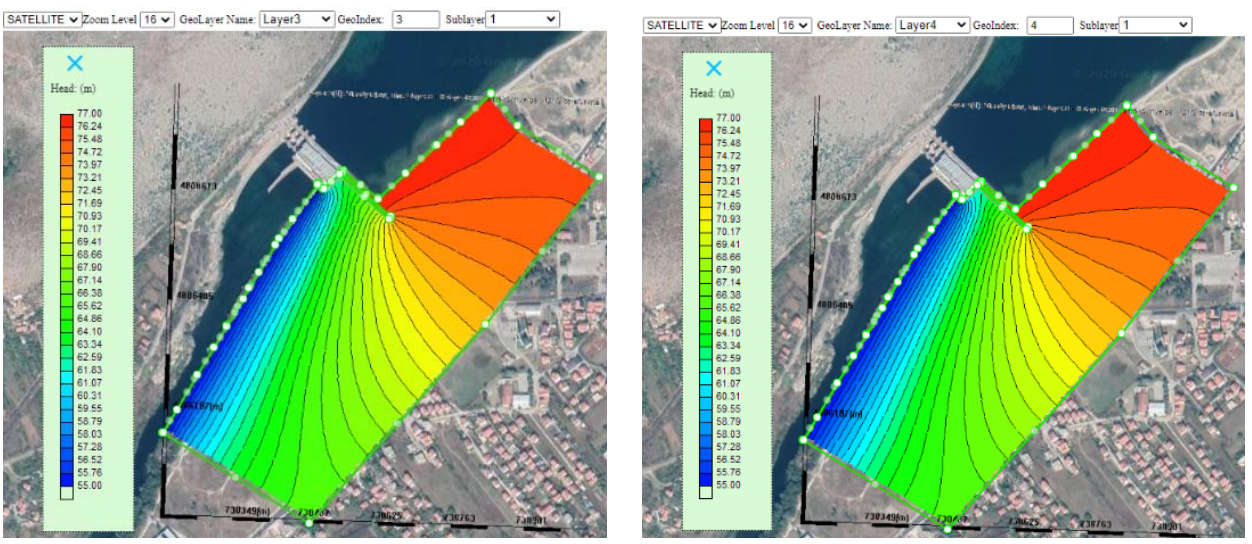

Figure 4. View of GWL by layers

The results of groundwater flow velocities by layers were also obtained. Observing the overall area of the model, it can be concluded that the highest groundwater flow velocities occur in the first layer, specifically in the area downstream of the left bank wall, at the place of discharge from the drainage channel. Table 2 shows the maximum values of velocities by layers.

Table 2. Maximum values of velocities by layers

\begin{tabular}{|c|c|}
\hline Layer & $\begin{array}{c}\text { Maximum value of velocity }(\mathrm{m} / \mathbf{s})- \\
\text { MAGNET Premium }\end{array}$ \\
\hline 1 & $6.38^{*} 10^{-3}$ \\
\hline 2 & $1.55^{*} 10^{-3}$ \\
\hline 3 & $1.78^{*} 10^{-4}$ \\
\hline 4 & $1.72^{*} 10^{-6}$ \\
\hline
\end{tabular}

The entire area of the boundary condition of head water of $77 \mathrm{~m}$ a.s.l. can be observed as the part through which water enters the domain, and the area of the boundary condition of tail water of $55 \mathrm{~m}$ a.s.l. as the part through which water flows out of the domain. The most active part is immediately downstream of the dam, on the left bank of Neretva, where weepholes are placed for discharge of these quantities of water. The model showed the total amount of water of $455.05 \mathrm{l} / \mathrm{s}$ that is filtered from the domain.

Transport simulation in the model required the values of the mass concentration that was introduced. The concentration was taken over from field research data. Dyeing in the field, at piezometer PL1/1, was done with $5 \mathrm{~kg}$ of sodium fluorescein by directly pouring through the borehole mouth and rinsing with $1.5 \mathrm{~m}^{3}$ of water. This gave a mass concentration value of $3.33 \mathrm{~kg} / \mathrm{m}^{3}$ with which the model was made. The results of the conducted simulation showed the occurrence of the tracer at the monitoring piezometer M5/2 two hours after the tracer was introduced in the piezometer. After 5 hours, the tracer concentration stabilized at a value of $6 \mathrm{mg} / \mathrm{l}$. 
Merdžo, P., Raič, M.

Hydraulic numerical analysis of groundwater in the left hinterland of the Mostar hydroelectric power plant dam

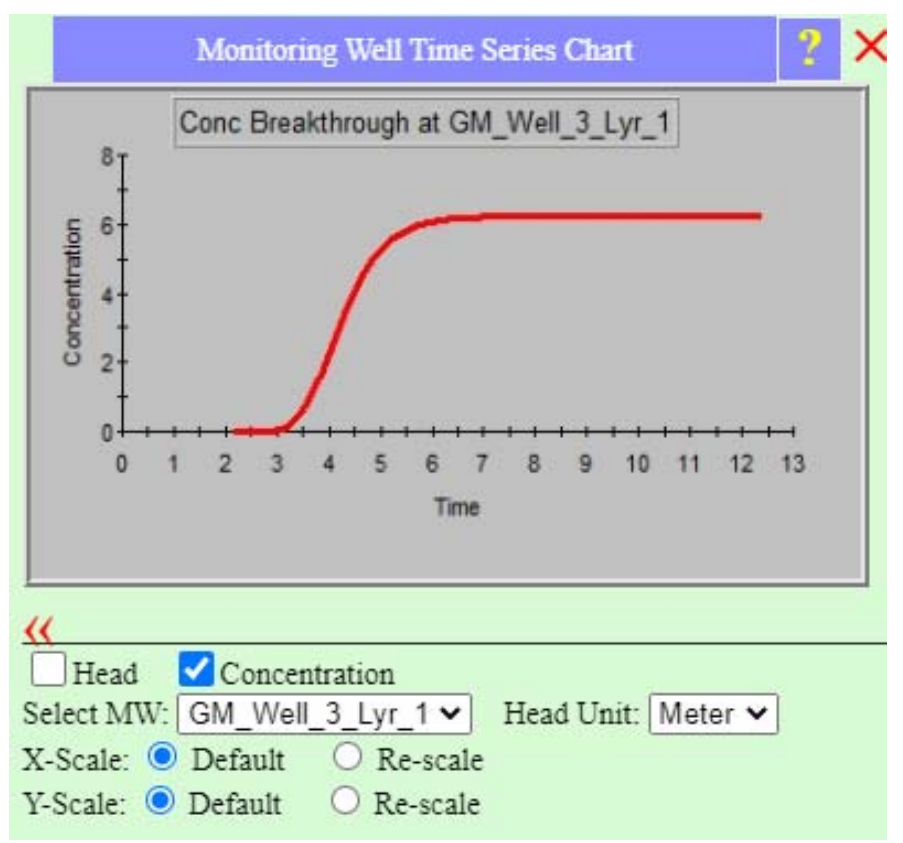

Figure 5. Curve of tracer concentration at the monitoring piezometer M5/2

\subsection{Verification}

Figure 5 shows a comparison of the GWL results obtained from the numerical models MAGNET 4 WATER and DHI WASY FEFLOW and the results measured in the field at each of the specified control piezometers. Greater deviations can be observed at piezometers located close to the diaphragm wall, occurring because of the direct connection between the head water level, or the water level in the reservoir, and the water level in these piezometers.

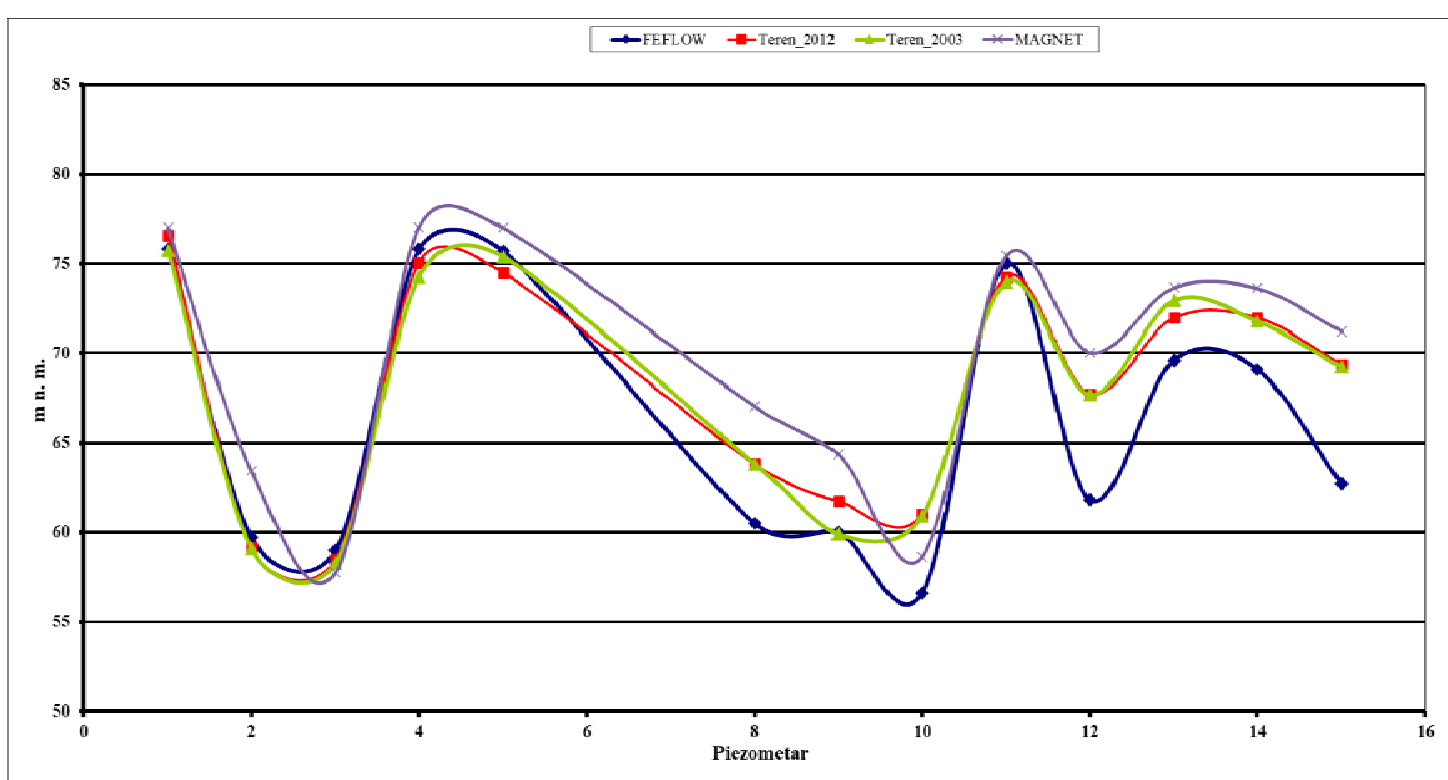

Figure 5. Comparison of GWL results obtained in MAGNET Premium, FEFLOW and field measurements 
Merdžo, P., Raič, M.

Hydraulic numerical analysis of groundwater in the left hinterland of the Mostar hydroelectric power plant dam

According to the geophysical investigation results from 2003, in the area of the left hinterland of the Mostar hydroelectric power plant, the effective groundwater flow velocity at the diaphragm break point is $\mathrm{v}_{\mathrm{ef}}=6.6 \cdot 10^{-3} \mathrm{~m} / \mathrm{s}$. The model in which the test was conducted resulted in a maximum value of velocity at the point of outflow from the drainage channel of $6.38^{*} 10^{-3} \mathrm{~m} / \mathrm{s}$, while in DHI WASY FEFLOW this velocity was $7.84^{*} 10^{-3} \mathrm{~m} / \mathrm{s}$. Table 3 gives a comparison of maximum velocity values by layers obtained in the Premium MAGNET 4 WATER and DHI WASY FEFLOW programs. Deviations in values are considered to be due to discretization of the grid used by the programs. FEFLOW uses triangle as a discretization element while in MAGNET it is regular quadrilateral.

Table 3. Maximum values of velocities by layers

\begin{tabular}{|c|c|c|}
\hline Layer & $\begin{array}{c}\text { Maximum value of velocity } \\
(\mathbf{m} / \mathbf{s})-\text { MAGNET Premium }\end{array}$ & $\begin{array}{c}\text { Maximum value of } \\
\text { velocity }(\mathbf{m} / \mathbf{s})-\text { FEFLOW }\end{array}$ \\
\hline 1 & $6.38^{*} 10^{-3}$ & $7.84^{*} 10^{-3}$ \\
\hline 2 & $1.55^{*} 10^{-4}$ & $3.03^{*} 10^{-3}$ \\
\hline 3 & $1.78^{*} 10^{-4}$ & $1.03^{*} 10^{-4}$ \\
\hline 4 & $1.72^{*} 10^{-6}$ & $8.97^{*} 10^{-5}$ \\
\hline
\end{tabular}

According to hydrological discharge volume measurements at weepholes, the total amount of water being filtered was approximately $348.40 \mathrm{l} / \mathrm{s}$. A comparison with numerical results is shown in Table 4.

Table 4. Quantity of water being filtered from the domain

\begin{tabular}{|c|c|}
\hline & $\begin{array}{c}\text { Quantity of water being filtered } \\
(\mathrm{I} / \mathrm{s})\end{array}$ \\
\hline TERRAIN & 348.40 \\
\hline MAGNET Premium & 455.05 \\
\hline FEFLOW & 326.01 \\
\hline
\end{tabular}

According to the tracing report, it was indicated that the tracer appeared at piezometer M5/2 3-4 hours after the tracer was injected in piezometer PL1/1. The actual concentration at piezometer M5/2 was $6.0 \mathrm{mg} / \mathrm{l}$. After the simulation was carried out in the DHI WASY FEFLOW program of the transport of the mass injected in piezometer PL1/1 in concentration of $3.33 \mathrm{~kg} / \mathrm{m}^{3}$, the modeled value of concentration at the point of piezometer $\mathrm{M} 5 / 2$ for a period of four hours from the moment of injection, which is also the time of first appearance of the tracer, is $5.50 \mathrm{mg} / \mathrm{l}$. In the Premium MAGNET 4 WATER program, the modeled tracer concentration value was $6 \mathrm{mg} / \mathrm{l}$ after 5 hours, which can be concluded to correspond to the field results of concentration of $6 \mathrm{mg} / \mathrm{l}$ which remained unchanged.

Table 5. Tracer concentration results

\begin{tabular}{|c|c|c|c|}
\hline & Terrain & FEFLOW & $\begin{array}{c}\text { MAGNET } \\
\text { Premium }\end{array}$ \\
\hline $\begin{array}{c}\text { Tracer concentration } \\
\text { [mg/l] }\end{array}$ & 6 & 5.5 & 6 \\
\hline
\end{tabular}


Merdžo, P., Raič, M.

Hydraulic numerical analysis of groundwater in the left hinterland of the Mostar hydroelectric power plant dam

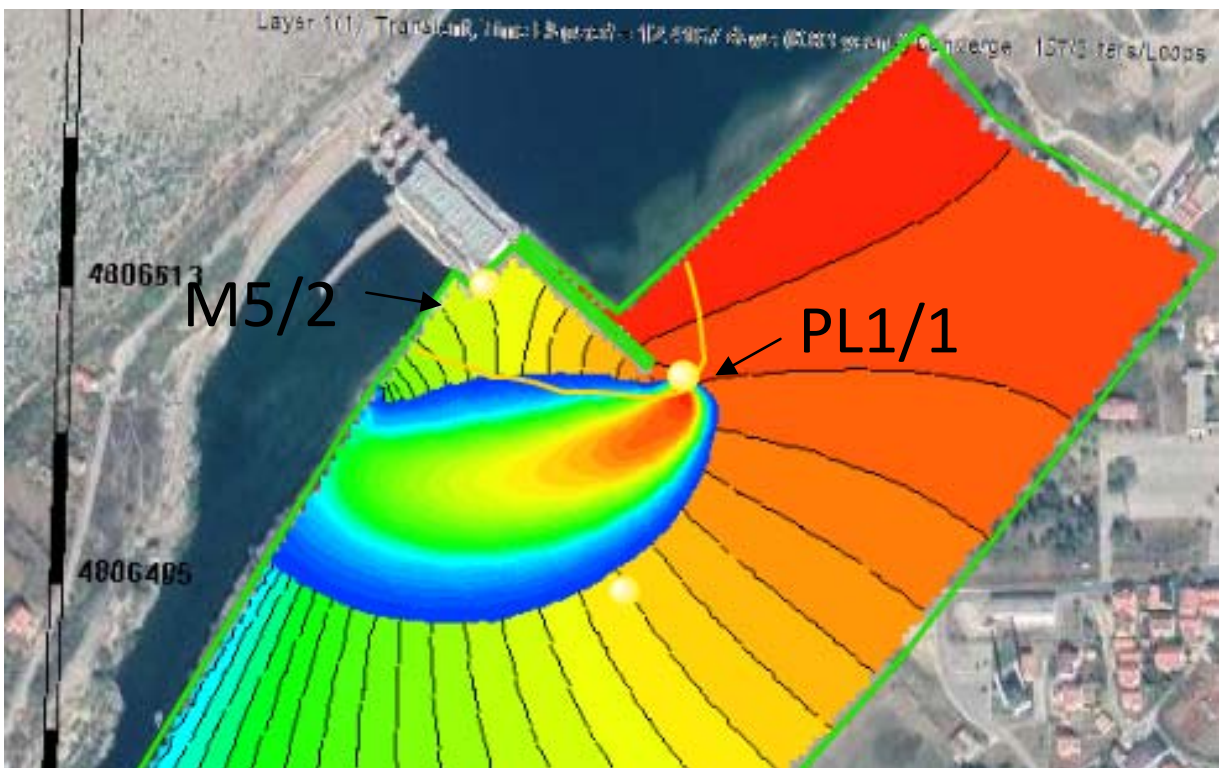

Figure 6. Tracer concentration around the diaphragm wall of HPP Mostar - MAGNET Premium

\section{CONCLUSION}

The modeling performed on the spatial stationary mathematical model of space of the left hinterland of the Mostar hydroelectric power plant made it possible to qualitatively assess the influence of existing hydroelectric power plant facilities on the filtration conditions in the considered area.

The paper showed that it is possible to obtain a good idea on groundwater conditions, with precisely defined geometry of the area, as well as thoroughly processed available geological data from a large number of boreholes in the area. Also, it has been confirmed that it is justified to use the MAGNET 4 WATER program for testing/ modeling in karst areas.

The paper also showed that the application of this modeling method can be widely used for determining the dominant directions of groundwater flows, and the determination of directions and intensity of dominant groundwater flows itself also defines the directions of possible contaminant transport.

Based on the compared results of mass transport, it can be concluded that the spatial conceptual model is suitable for examining transport underground the left hinterland of HPP Mostar.

The used spatial stationary model of the left hinterland of the Mostar hydroelectric power plant confirms that it is the basis for further development of the non-stationary model and for its needs it is necessary to constantly update its database with new observation data.

\section{REFERENCES}

1. JP Elektroprivreda HZ HB - brochure HE Mostar, Mostar, November 2013. 
Merdžo, P., Raič, M.

Hydraulic numerical analysis of groundwater in the left hinterland of the Mostar hydroelectric power plant dam

2. Raič, M.: Determining the area and intensity of seepage in the left hinterland of the Mostar hydroelectric power plant dam, Master's thesis, Faculty of Civil Engineering, Architecture and Geodesy in Split, Split, 2012.

3. https://izgradnjahemostar.wordpress.com/2015/03/13/sloj-uglja-u-lijevom-boku-2-oktobar1985/

4. Project "Renewal of the technical measurement system and exploration of the situation underground the left hinterland and dam of HPP Mostar - Phase II", Faculty of Civil Engineering, University of Mostar, 2005.

5. https://www.magnet4water.com/Main.aspx?caller=magnet-user-manual.html

6. Merdžo, P.: Hydraulic numerical analysis of groundwater in the left hinterland of the Mostar hydroelectric power plant dam, Graduation thesis, University of Mostar, Faculty of Civil Engineering, Mostar, 2020. 